
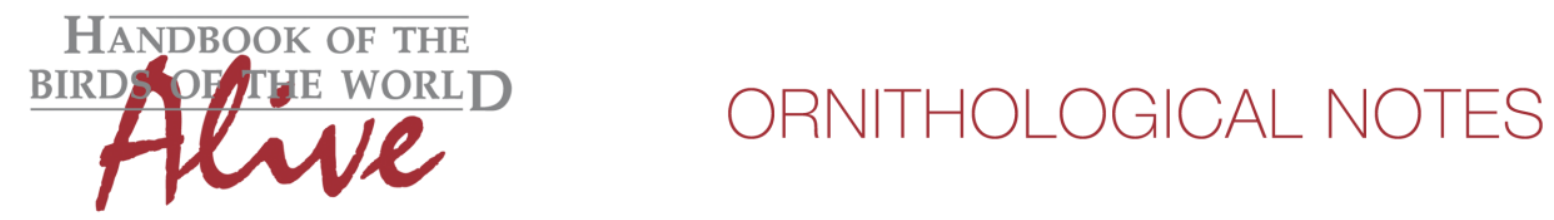

\title{
Notes on the vocalizations of Rufous Fantail (Rhipidura rufifrons)
}

Peter Boesman

In the following we briefly analyze and compare voice of the different races of Rufous Fantail

(Rhipidura rufifrons). We also try to quantify the extent of any vocal differences using the criteria proposed by Tobias et al. (2010), as a support for taxonomic review.

We have made use of sound recordings available on-line from Xeno Canto (XC), Macaulay Library $(\mathrm{ML})$, Avian Vocalizations Center (AVoCet) and The Internet Bird Collection (IBC).

With eighteen subspecies, many confined to single islands, this is obviously a very complex group, to say the least. This note is therefore rather a preliminary analysis, based on available recordings, which per race are often just a few or less.

An overview of vocalizations per race (some already grouped):

R.r. intermedia/rufifrons (Australian Rufous Fantail): Song is a high-pitched series of notes with a seesawing pattern

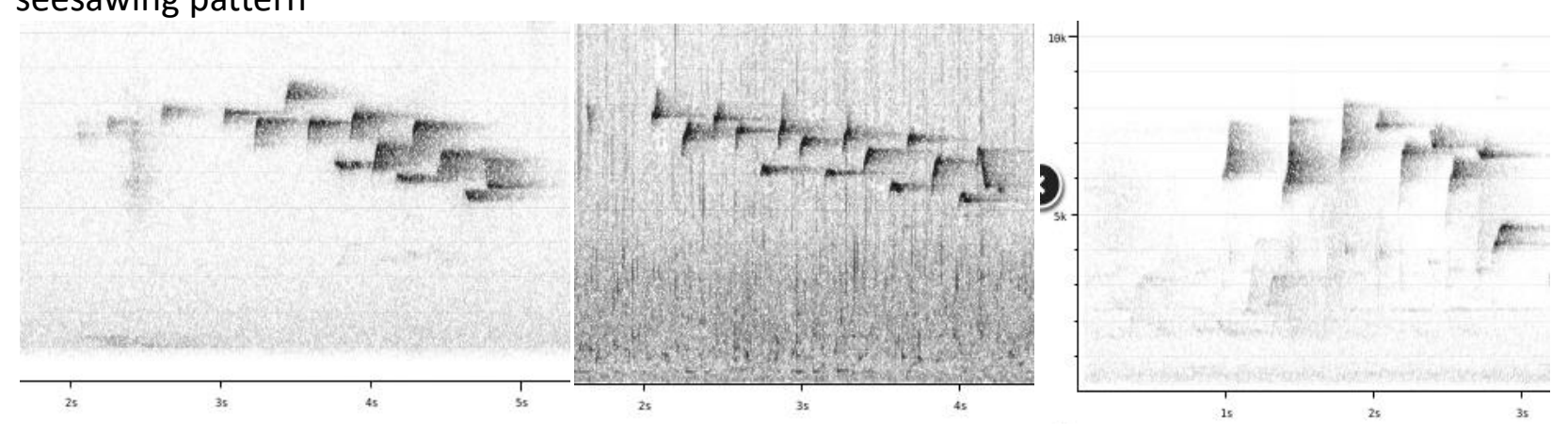

R.r. louisiadensis(?) (SE New Guinea Island birds): Song is a more loosely given whistled song, much lower-pitched than previous.

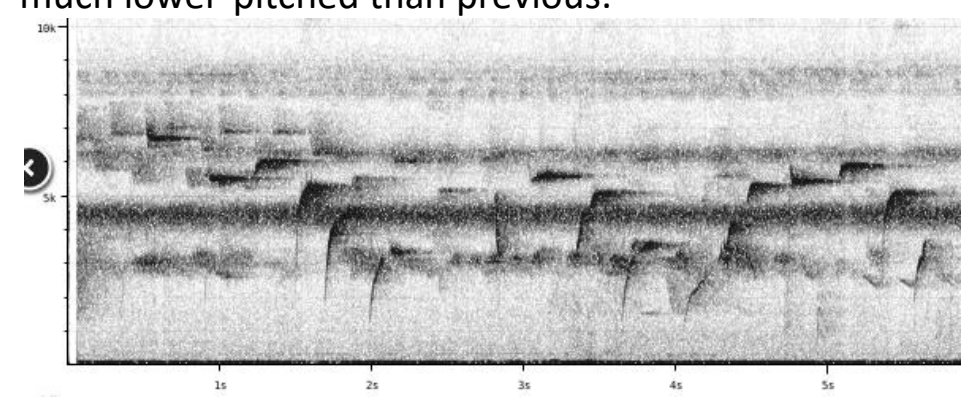


HANDBOOK OF THE

BIRDPPIVE WORLD ORNITHOLOGICAL NOTES

R.r.russata (+ rufofronta, commoda, granti) (Solomon Fantail): Song is a series of high-pitched notes, with ascending or descending patterns.

russata

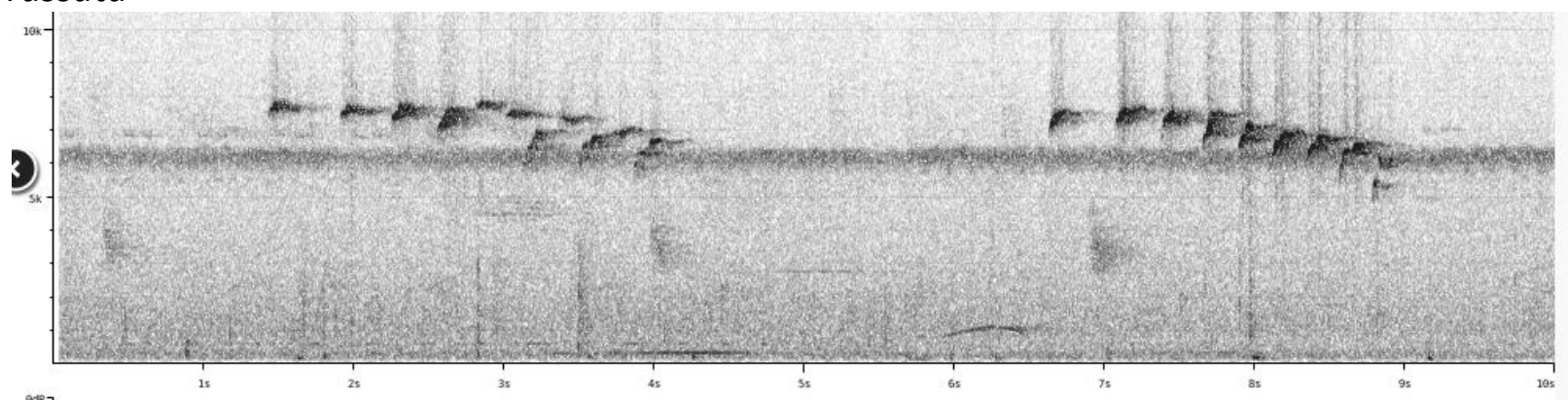

rufofronta

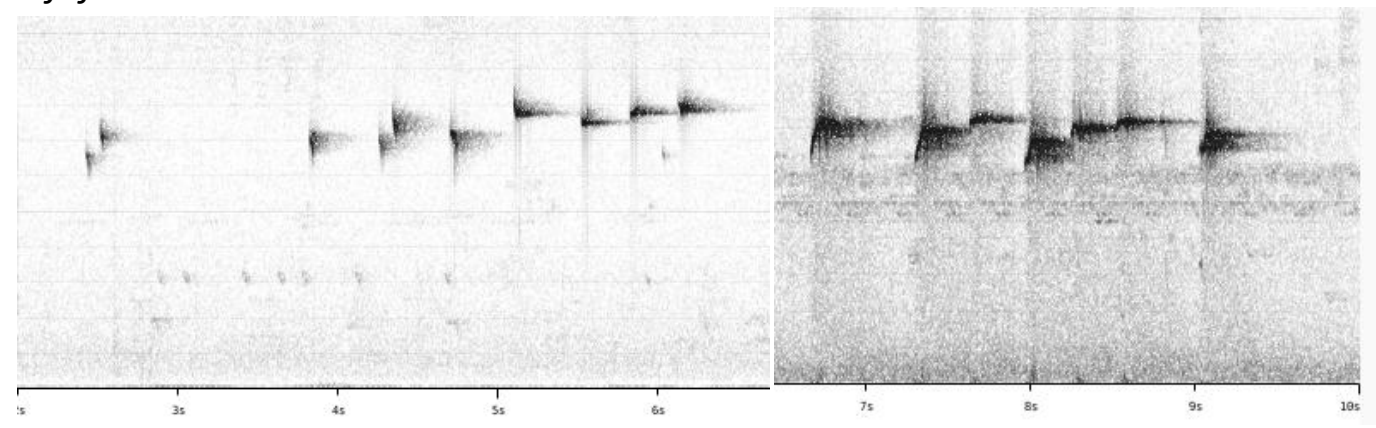

commode
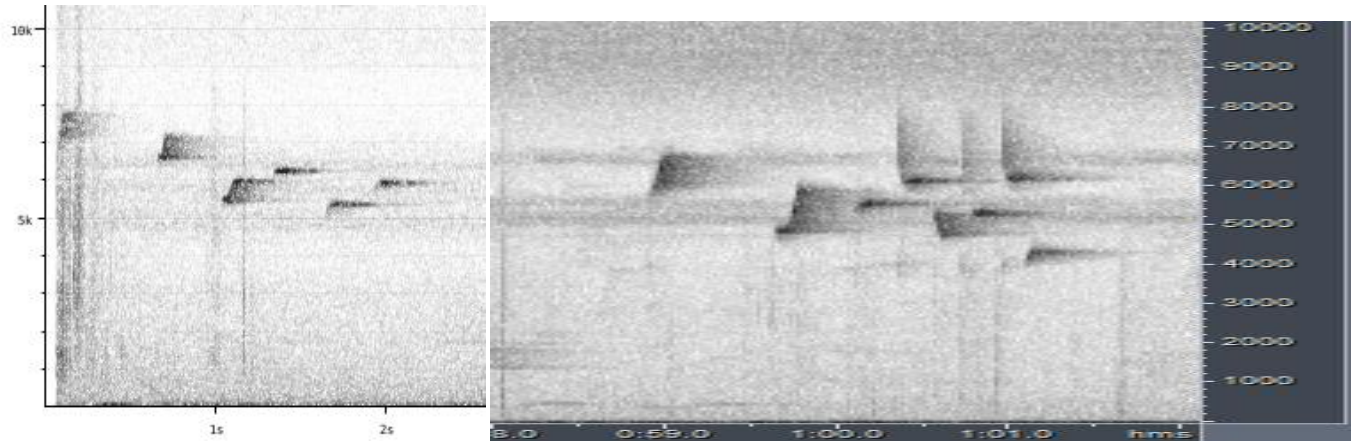

grant

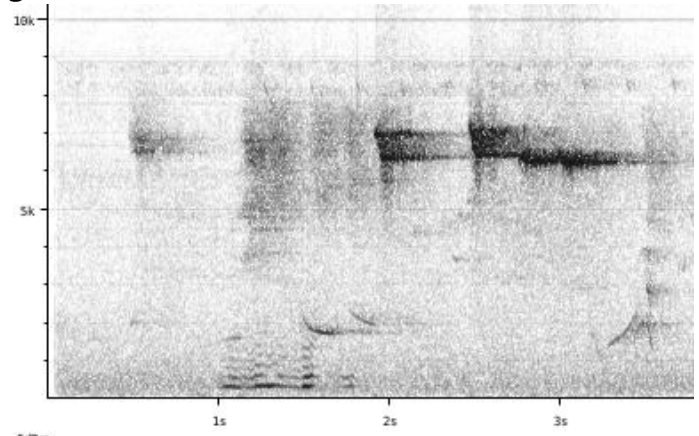

2 


\section{HANDBOOK OF THE}

BIRDSPF TUE WORLD

\section{ORNITHOLOGICAL NOTES}

R.r.utupae (+ melanolaema) (Santa Cruz Islands Fantail): Song is a series of staccato emphatic high-pitched notes, in a narrow frequency range.

utupae

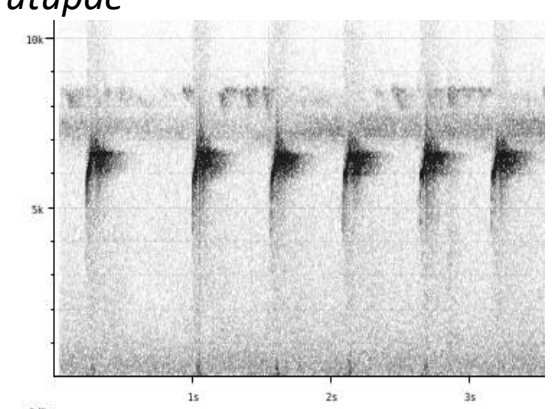

melanolaema

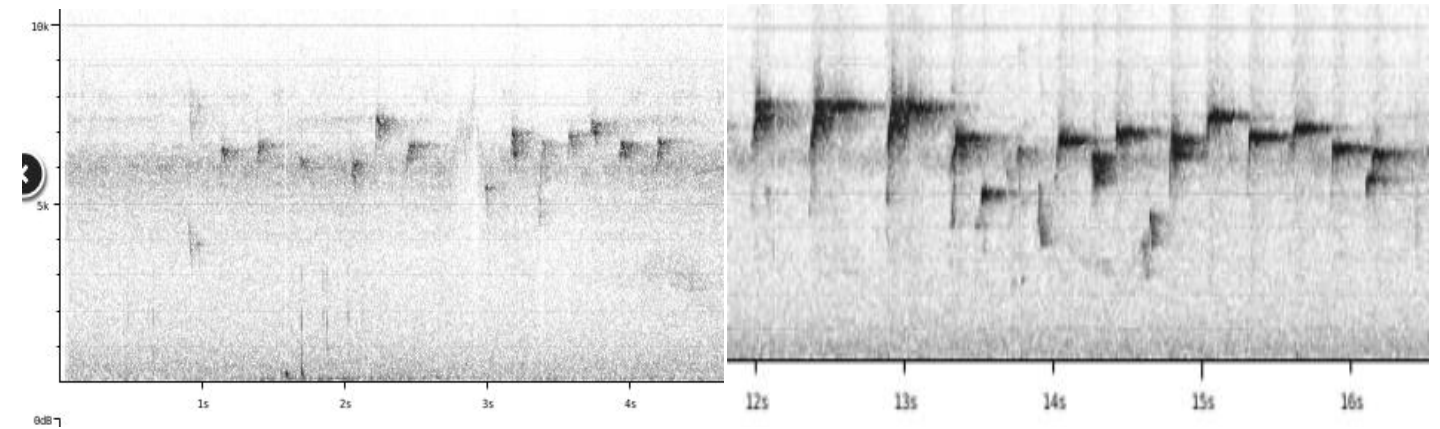

R.r.saipanensis (+ mariae) (Micronesian Fantail): Song is very different from above groups, a series of rich whistles descending in pitch. Most notes are sharply upslurred.

saipanensis
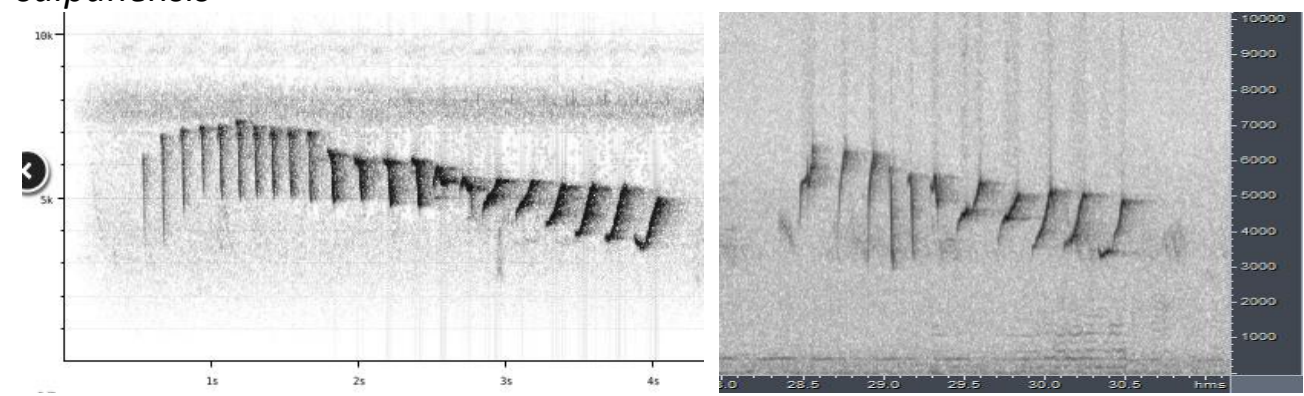

mariae
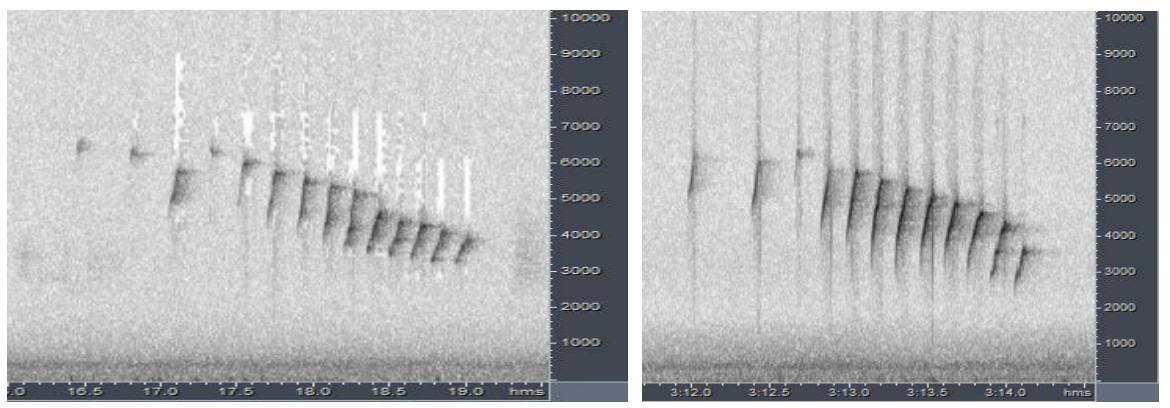

Guam (race uraniae??) Song slightly different, as upslurred notes seem to break up in 2 distinct notes, but kept within this vocal group. 


\section{HANDBOOK OF THE Alve}

\section{ORNITHOLOGICAL NOTES}
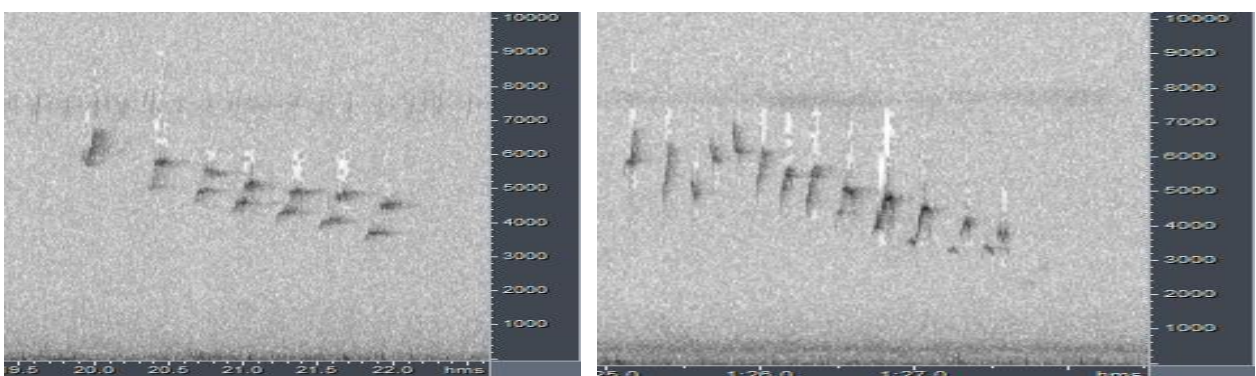

R.r. versicolor (Yap Fantail): Song starts with some short staccato notes which gradually become longer changing into some sweet whistles.

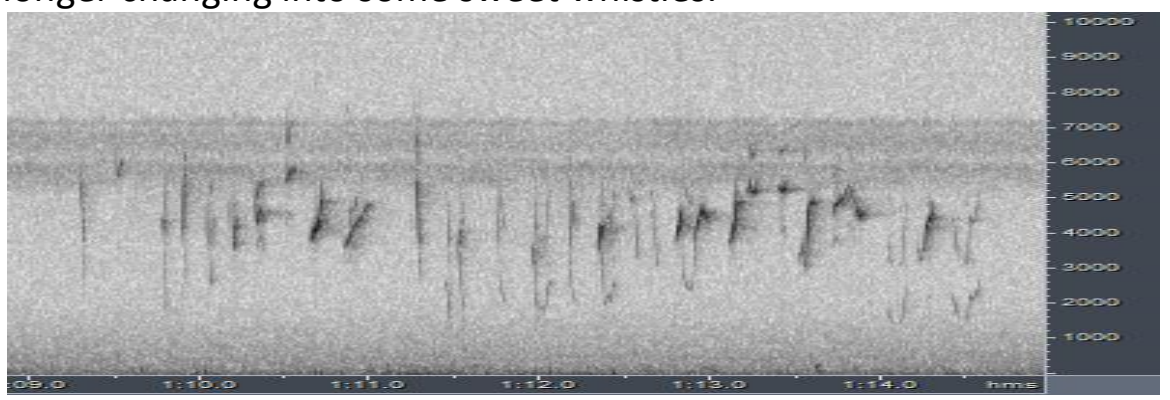

R.r.kubaryi (Pohnpei Fantail): a series of high-pitched staccato notes

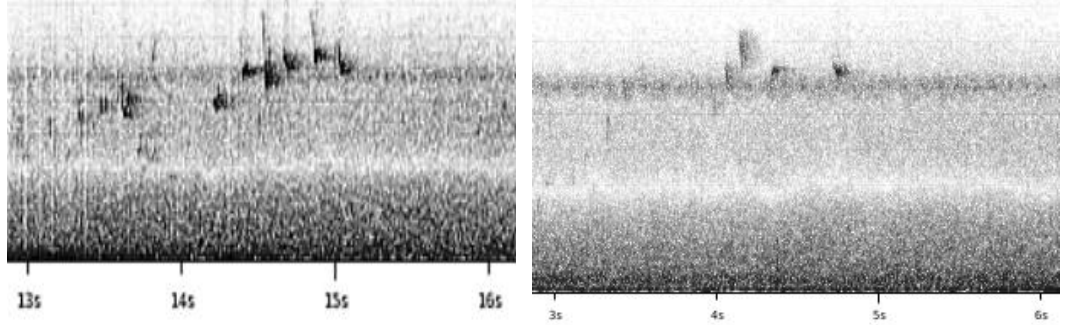

R.r. torrida (Gilolo Fantail): a series of high-pitched staccato notes without a clear pattern
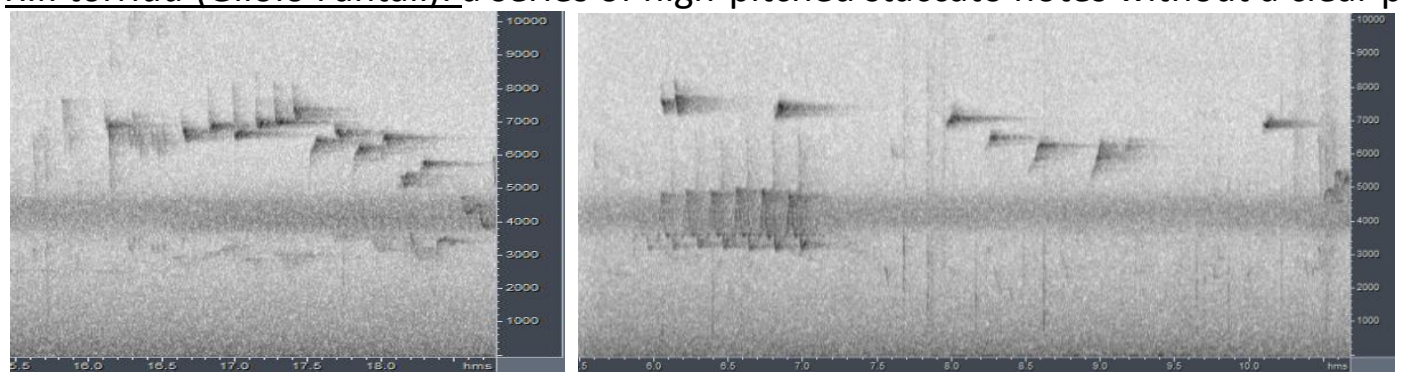

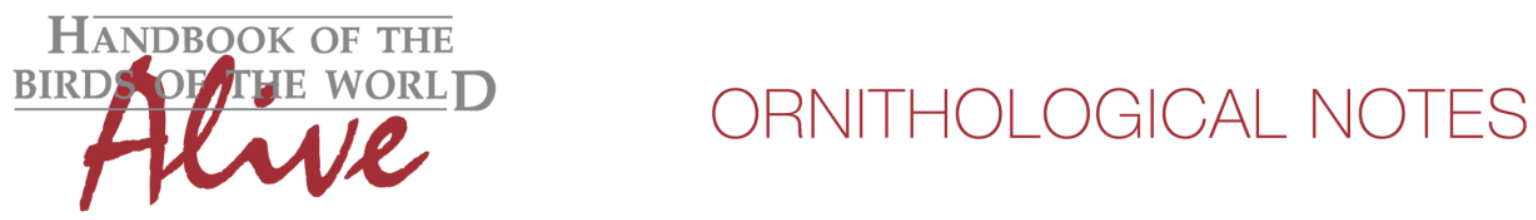

Given that we have very few recordings of several races and that there is a fair amount of variation in song, a reliable analysis at present is difficult.

We have tried to compare and quantify the vocal differences of all groups with a rough estimated score in a comparison table:

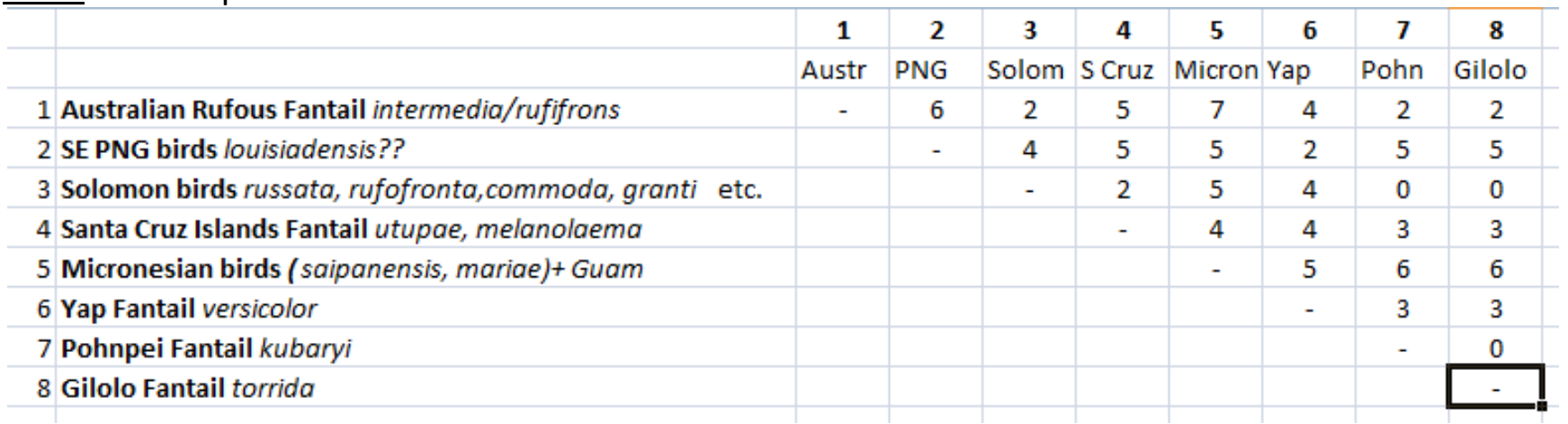

Some groups are convincingly vocally different (e.g. group 1 (Australia), group 2 (SE PNG) and group 5 (Micronesia)), others much less so (partially due to the fact that the Solomon group stays quite a mixed bag, and as a consequence, e.g. Gilolo and Pohnpei Fantail seem to fall within the range of vocalizations of the Solomon group).

This note was finalized on 1st March 2016, using sound recordings available on-line at that moment. We would like to thank in particular the sound recordists who placed their recordings for this species on XC and ML: Patrik Åberg, Marc Anderson, James Bradley, Fernand Deroussen, John Dumbacher, David Gibbs, Phil Gregory, Niels Krabbe, Frank Lambert, John Mittermeier, Mike Nelson, Douglas Pratt, Mark Robbins and Mark Todd.

\section{References}

Tobias, J.A., Seddon, N., Spottiswoode, C.N., Pilgrim, J.D., Fishpool, L.D.C. \& Collar, N.J. (2010). Quantitative criteria for species delimitation. Ibis 152(4): 724-746.

\section{Recommended citation}

Boesman, P. (2016). Notes on the vocalizations of Rufous Fantail (Rhipidura rufifrons). HBW Alive Ornithological Note 188. In: Handbook of the Birds of the World Alive. Lynx Edicions, Barcelona. (retrieved from http://www.hbw.com/node/932129 on 26 August 2016). 